\title{
Feeding habits of two deep-sea sharks from central- northern Chile: hooktooth dogfish Aculeola nigra (Etmopteridae) and dusky catshark Bythalaelurus canescens (Scyliorhinidae)
}

Hábitos alimentarios de dos tiburones de profundidad del centro-norte de Chile: tollo negro de cachos Aculeola nigra (Etmopteridae) y pejegato oscuro Bythalaelurus canescens (Scyliorhinidae)

\section{Enzo Acuña ${ }^{1}$ and Juan Carlos Villarroel ${ }^{1,2}$}

${ }^{1}$ Departamento de Biología Marina, Facultad de Ciencias del Mar, Universidad Católica del Norte, Casilla 117, Coquimbo, Chile. eacuna@ucn.cl

${ }^{2}$ Dirección actual: Dirección Zonal de Pesca XV, I y II regiones, Avda. Arturo Prat 920, Iquique, Chile

\begin{abstract}
Feeding habits of 381 specimens of Aculeola nigra and 513 specimens of Bythalaelurus canescens were studied. In 121 stomachs of A. nigra and 312 of B. canescens preys were found. Individuals were collected as bycatch from the deep-sea crustacean fishery, between 2520'S and 35\%43'S; from J anuary 1997 to J uly 2000 off the northern-central Chilean coast. The most important prey by index of relative importance and by frequency of occurrence in A. nigra was the benthic deep-sea shrimp Heterocarpus reedi; while by number the euphausiid Euphausia mucronata and by weight the common hake Merluccius gayi were the most important. The deep-sea shrimp $H$. reedi was also the most important prey of $B$. canescens, for all feeding indices used. Significant differences were found in the habitat where these predators consume their prey, A. nigra eating more on pelagic prey; whereas B. canescens feeds more on benthic prey. A. nigra showed a higher trophic niche breadth, because they predate more on benthic, pelagic and mesopelagic resources; whereas B. canescens feeds primarily on benthic prey. The diet of both species significantly overlapped, suggesting a high competition between them.
\end{abstract}

Key words: By-catch, pelagic, benthic, trophic niche breadth, trophic overlap

\section{INTRODUCTION}

The biology of deep-sea sharks is poorly known compared to that of their shallower-waters relatives, although deepsea sharks are important top predators occupying a high trophic level (Cortés 1999). Therefore the study of deepsea sharks distribution, biology and ecology is essential to better understand the dynamics of communities inhabiting this environment. According to Gartner et al. (1997) the largest predators in the deep-sea are sharks, but only the smaller shark species have been well studied.

Recent efforts have been made to study the biodiversity, life history and fisheries of deep-sea chondrichthyans, but the understanding of deep-sea fauna is considerably behind the level of knowledge of some inshore and pelagic chondrichthyans (Kyne \& Simpfendorfer 2007). Knowledge of deep-sea sharks in the Southeastern Pacific Ocean off Chile is restricted mainly to taxonomy, systematic and distribution (Compagno 1984, Meléndez \& Meneses 1989, Pequeño 1989), while their reproduction and feeding habits have been poorly described (Burgess \& Springer 1986, Arancibia \& Meléndez 1987).
Determining the trophic relationships among species helps understanding their community organization and effect on their ecosystem (Krebs 1989). The trophic relationships between marine organisms are complex, involving different intra and inter-specific strategies for occupying separate ecological niches to partition food resources and this allows exploitation of different resources and habitats (Hyndes et al. 1997). This kind of research has been described for three shark species and a ray in nearshore waters of a large subtropical embayment (White et al. 2004), and in four carcharhinid sharks around the Hawaiian Islands (Papastamatiou et al. 2006).

Chondrichthyan fishes are by-catched in the deep sea shrimp trawl fishery along central-northern Chile. They comprise $9.28 \%$ by weight of by-catched fishes and include at least ten shark, four ray and one chimaerid species, but only two shark species are relatively important in the catch, the hooktooth dogfish Aculeola nigra and the dusky catshark Bythalaelurus canescens, which account for $49 \%$ and $20.3 \%$ of the condrichthyans, respectively (Acuña \& Villarroel 2002). 
Aculeola nigra de Buen, 1959 (Etmopteridae) is found only in the southeastern Pacific Ocean between Trujillo,

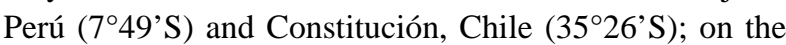
continental shelf and upper slope between 110 and $735 \mathrm{~m}$ depth (Meléndez \& Meneses 1989). Bythalaelurus canescens Günther, 1878 (Scyliorhinidae) is distributed from Southern Ecuador to the Strait of Magellan (Compagno 1984). Its bathymetric distribution ranges between 250 and 1,260 m depth (Meléndez \& Meneses 1989). Both species are particularly abundant below $300 \mathrm{~m}$ depth, as indicated by catches in the deep-sea shrimp Heterocarpus reedi fishery (González 2001). However, although they occupy the same spatial distribution, several aspects on their ecology have not been studied. The aim of this study is to describe the feeding habits; trophic niche breadth and diet overlap of these two species.

\section{Material AND METHOds}

Specimens of the deep-sea sharks A. nigra and $B$. canescens were obtained between February 1997 and July 2000 from by-catch of the deep-sea shrimp fishery existing between $25^{\circ} 20^{\prime} \mathrm{S}$ and $35^{\circ} 43^{\prime} \mathrm{S}$. Depth of sampling ranged between 115 and $480 \mathrm{~m}$. Sharks were retained on ice onboard the vessel, and then taken to the laboratory for further analysis. Subsequently, specimens were sexed and measured (nearest $1 \mathrm{~mm} \mathrm{TL}$ ). Stomachs were extracted and preserved in $10 \%$ formalin. The stomachs were dissected and all prey items identified to the lowest possible taxa using classifications from Roper et al. (1984) for Cephalopoda, Manning (1968) for Stomatopoda, Retamal (1994) for Decapoda, Mauchline \& Fisher (1969) for Euphausiacea and Nelson (1994) for Teleostei. Prey items were counted and their total wet weight was determined.

The minimum number of stomachs to be analyzed by species was estimated using the cumulative prey curves obtained from randomly pooled subsets of stomachs of each species according to Cortés (1997).

The numeric $(\mathrm{N})$, gravimetric $(\mathrm{W})$, frequency of occurrence (FO) (Cortés 1997) and relative importance (IRI) indices (Pinkas et al. 1971) were used for the analysis of feeding habits.

Similarity percentages were used to determine which prey items characterized the diets of each species and made the highest contributions to dissimilarities between both species (Clarke 1993). PRIMER v5 (Clarke \& Gorley 2001) was used on each dietary indices described above.
The IRI was used to determine trophic niche-breadth for each species by means of the Shannon-Wiener index $\left(H^{\prime}\right)$ (Krebs 1989) and is expressed as:

$$
H^{\prime}=-\sum p_{j} \log p_{j}
$$

Where $H^{\prime}$ is the Shannon-Wiener measure of trophic niche-breadth and $p_{j}$ is the proportion of the IRI. A high $H^{\prime}$ value indicates feeding on a higher spectrum width of prey-items.

The Shannon-Wiener measure $H^{\prime}$ ' was standardized on a 0 - 1 scale using the evenness measure $J$ ' which is expressed as:

$$
J^{\prime}=\frac{H^{\prime}}{\log n}
$$

Where $J^{\prime}$ is the evenness measure of the ShannonWiener function and $n$ is the total number of prey items. A high $J$ ' indicates a fish feeding on a relatively larger number of a few main prey types (Shuozeng 1995).

The degree of trophic overlap between species was estimated by means of the simplified Morisita index (C) (Krebs 1989). The value of $C$ varies from 0 for no overlap to 1 for complete overlap, with a value of $\geq 0.6$ being considered to be significant (Hyndes et al. 1997). This measure is expressed as:

$$
C=\frac{2 \sum p_{i j} p_{i k}}{\sum p_{i j}^{2}+\sum p_{i k}^{2}}
$$

Where $\mathrm{C}$ is the simplified Morisita index of trophic niche overlap between species $j$ and $k$ and $p_{i j}$ and $p_{i k}$ are the proportion of prey-item $i$ consumed by species $j$ and $k$, respectively.

\section{Results}

A total of 381 specimens of A. nigra and 513 specimens of $B$. canescens were collected during this study. The sizefrequency distribution of $A$. nigra showed that the mode for males was around $45 \mathrm{~cm}$ total length (TL), while the mode for females was at $50 \mathrm{~cm}$ TL. Both sexes of $B$. canescens had a smallest mode at around $30 \mathrm{~cm}$ TL (Fig. 1). 


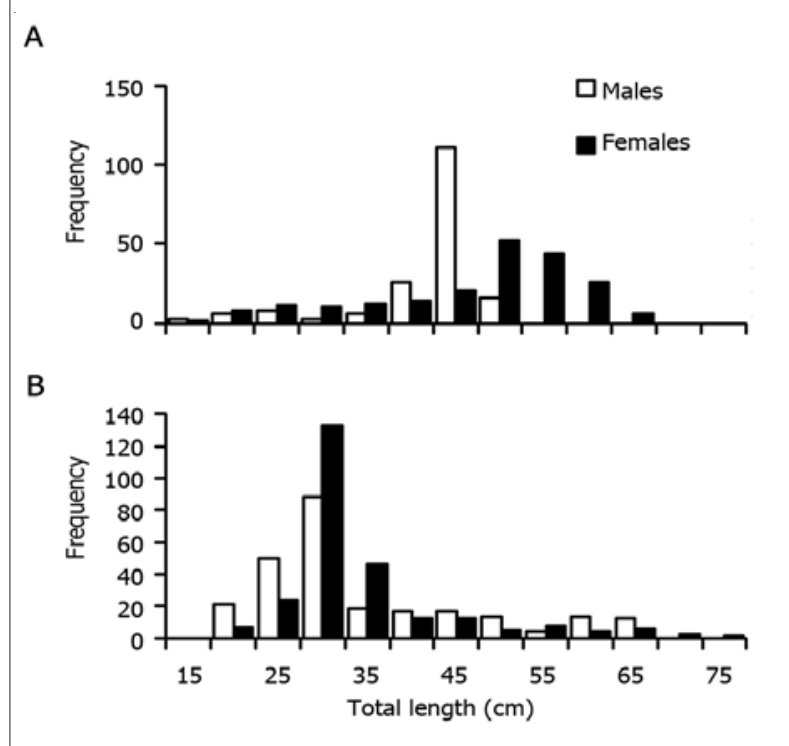

Figure 1. Size-frequency distribution by sex for; A) Aculeola nigra and B) Bythalaelurus canescens, obtained from by-catch of the deep-sea shrimp fishery between 1997 and 2000 / Distribución de frecuencia de tallas, por sexo de A) Aculeola nigra y B) Bythalaelurus canescens obtenidos como fauna asociada a la pesquería de camarón nailon entre 1997 y 2000

The minimum sample size of stomachs to study feeding habits of these species using cumulative prey curves was determined to be 24 stomachs for $A$. nigra and 26 stomachs for B. canescens (Fig. 2).

In A. nigra, the most important prey species by number was the euphausiid Euphausia mucronata, followed by the myctophid Diogenichthys laternatus, both pelagic preys. By weight the most important $A$. nigra identified prey was the hake Merluccius gayi. However, according to the frequency of occurrence and relative importance indices, the benthic prey Heterocarpus reedi was the single most important prey item of this species.

Heterocarpus reedi was also the most important prey of $B$. canescens, by number, weight, frequency of occurrence and relative importance indices. For both species a high percentage of unidentified fishes, crustacean and digested remains were found. Aculeola nigra had a high percentage by number of pelagic preys in its diet, being also important by weight, occurrence and relative importance (20.6\%, $11.1 \%$ and $13.7 \%$, respectively). Bythaelurus canescens feeds mainly upon benthic prey by number, weight, frequency of occurrence and relative importance, while pelagic prey showed percentages between 0.2 and $3.7 \%$ (Table 1). Chunks of saury Scomberesox saurus and rattail fish Nezumia pulchella were also found in two and one stomach of A. nigra, respectively.

An average dissimilarity of $46.51 \%$ was obtained when using the numeric index $(\% \mathrm{~N})$, with E. mucronata contributing with the highest percentage, followed by $D$. laternatus and $H$. reedi (Table 2 ). When using \%W the average dissimilarity was $41.6 \%$, with $D$. laternatus contributing with the highest percentage, followed by $M$. gayi and mud as a dietary category as in Carrasson et al. (1992) and White et al. (2004). An average dissimilarity of $29.27 \%$ was obtained when using the frequency of occurrence index (\%FO), with mud contributing with the highest percentage, followed by D. laternatus and unidentified cephalopods and Lophorochinia parabranchia (Table 2). Finally, when using \% IRI the average dissimilarity was $37.29 \%$ with $D$. laternatus contributing with the highest percentage, followed by mud, unidentified cephalopods and $H$. reedi (Table 2). A trophic niche breadth of $H^{\prime}=3.01$ and an evenness index of $J^{\prime}=0.68$ were estimated for A. nigra, parameters which were higher than for $B$. canescens, where $H^{\prime}=2.34$ and $J^{\prime}=0.52$ were found. Feeding of both species showed a significant overlap of $80 \%$.

\section{Discussion}

Stevens et al. (2000) pointed out that when sharks are taken as by-catch, they are often subject to high fishing mortality and may be virtually eliminated from large regions altering size structure and population parameters. This can

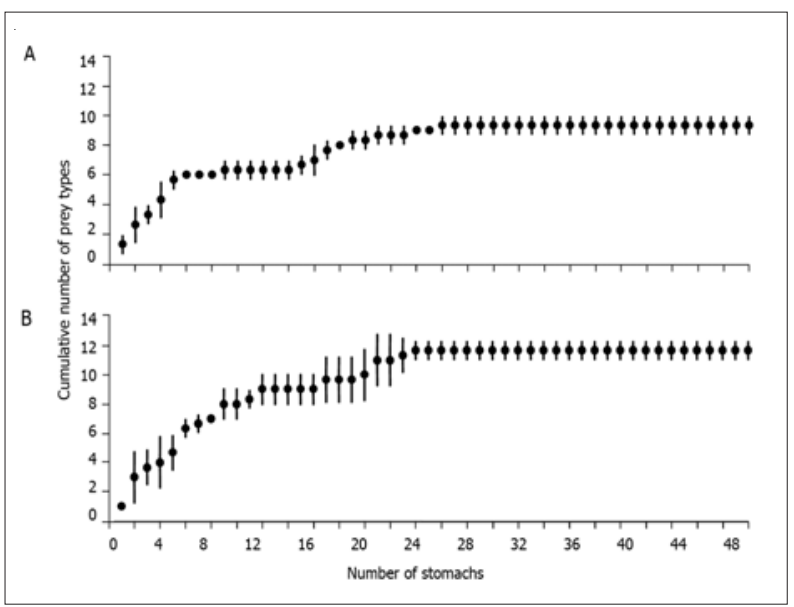

Figure 2. Cumulative prey curves for A) Bythalaelurus canescens and B) Aculeola nigra. Bars show standard error for three mean randomly pooled stomach sets / Curva acumulativa de presas de A) Bythalaelurus canescens y B) Aculeola nigra. Las barras muestran el error estandar de tres grupos promedio de estómagos conformados al azar 
Table 1. Prey-item, prey type, percentage by number (\%N), weight (\%W), frequency of occurrence (\%FO) and index of relative importance (\%RI) for Aculeola nigra and Bythalaelurus canescens. Maximum values are in bold / Ítem presa, Tipo de Presa, Porcentaje numérico (\%), gravimétrico (\%N), frecuencia de ocurrencia (\%O) índice de importancia relativa (\%RI) para Aculeola nigra y Bythalaelurus canescens. Los valores máximos se muestran en negrita

\begin{tabular}{|c|c|c|c|c|c|c|c|c|c|}
\hline \multirow[b]{2}{*}{ Prey-item } & \multirow[b]{2}{*}{ Prey type } & \multicolumn{4}{|c|}{ A. nigra } & \multicolumn{4}{|c|}{ B. canescens } \\
\hline & & $\% \mathrm{~N}$ & $\% \mathrm{~W}$ & $\% \mathrm{FO}$ & \%IRI & $\% \mathrm{~N}$ & $\% \mathrm{~W}$ & $\% \mathrm{FO}$ & \%IRI \\
\hline POLYCHAETA & Benthic & & & & & 0.4 & 0.1 & 0.3 & $<0.1$ \\
\hline \multicolumn{10}{|l|}{ MOLLUSCA } \\
\hline \multicolumn{10}{|l|}{ Cephalopoda } \\
\hline Loligo gahi & Pelagic & 0.5 & 0.1 & 0.8 & $<0.1$ & 0.9 & 0.1 & 0.6 & $<0.1$ \\
\hline Unidentified cephalopods & & 5.9 & 4.0 & 8.3 & 5.5 & 1.3 & 0.3 & 1.0 & 0.1 \\
\hline \multicolumn{10}{|l|}{ CRUSTACEA } \\
\hline \multicolumn{10}{|l|}{ Squillidae } \\
\hline Pterygosquilla armata & Benthic & 0.5 & 0.4 & 0.8 & $<0.1$ & 4.4 & 3.2 & 2.9 & 0.9 \\
\hline \multicolumn{10}{|l|}{ Euphausiidae } \\
\hline Euphausia mucronata & Pelagic & 37.9 & 0.3 & 1.5 & 3.9 & 0.9 & 0.2 & 0.6 & $<0.1$ \\
\hline \multicolumn{10}{|l|}{ Solenoceridae } \\
\hline Haliporoides diomedeae & Benthic & & & & & 0.4 & 0.7 & 0.3 & $<0.1$ \\
\hline \multicolumn{10}{|l|}{ Pasiphaidea } \\
\hline Pasiphaea acutifrons & Pelagic & & & & & 0.9 & 0.2 & 0.6 & $<0.1$ \\
\hline \multicolumn{10}{|l|}{ Pandalidae } \\
\hline Heterocarpus reedi & Benthic & 11.3 & 8.9 & 15.8 & 21.6 & 37.1 & 27.1 & 17.6 & 45.3 \\
\hline \multicolumn{10}{|l|}{ Glyphocrangonidae } \\
\hline Glyphocrangon alata & Benthic & & & & & 2.6 & 2.6 & 1.3 & 0.3 \\
\hline \multicolumn{10}{|l|}{ Polychelidae } \\
\hline Stereomastis suhmi & Benthic & & & & & 0.4 & 0.4 & 0.3 & $<0.1$ \\
\hline \multicolumn{10}{|l|}{ Galatheidae } \\
\hline Cervimunida johni & Benthic & 2.5 & 3.6 & 3.8 & 1.5 & 3.9 & 3.8 & 2.6 & 0.8 \\
\hline Pleuroncodes monodon & Benthic & 4.4 & 4.0 & 5.3 & 3.0 & 5.7 & 6.2 & 4.2 & 2.0 \\
\hline Unidentified galatheids & & 0.5 & 0.2 & 0.8 & $<0.1$ & 0.4 & 0.1 & 0.3 & $<0.1$ \\
\hline \multicolumn{10}{|l|}{ Calappidae } \\
\hline Mursia gaudichaudii & Benthic & & & & & 1.7 & 1.8 & 1.3 & 0.2 \\
\hline Majidae & & & & & & & & & \\
\hline Lophorochinia parabranchia & Benthic & & & & & 4.8 & 2.7 & 3.5 & 1.1 \\
\hline Cancridae & & & & & & & & & \\
\hline Cancer porteri & Benthic & & & & & 0.9 & 0.9 & 0.3 & $<0.1$ \\
\hline Unidentified crustaceans & & 4.4 & 1.7 & 6.8 & 2.8 & 10.5 & 8.2 & 7.7 & 5.8 \\
\hline Crustacean remains & & & 1.4 & 7.5 & 0.7 & & 9.9 & 19.2 & 7.6 \\
\hline TELEOSTEI & & & & & & & & & \\
\hline Notosudidae & & & & & & & & & \\
\hline Scopelosaurus sp. & Benthic & 0.5 & 0.7 & 0.8 & 0.1 & & & & \\
\hline Myctophidae & & & & & & & & & \\
\hline Diogenichthys laternatus & Pelagic & 15.3 & 7.1 & 4.5 & 6.8 & & & & \\
\hline Protomyctophum chilensis & Pelagic & 0.5 & 0.6 & 0.8 & 0.1 & & & & \\
\hline Lampanyctus iselinoides & Pelagic & 0.5 & 0.2 & 0.5 & $<0.1$ & & & & \\
\hline Unidentified myctophids & Pelagic & 3.0 & 8.3 & 3.0 & 2.3 & 1.3 & 3.3 & 1.0 & 0.2 \\
\hline Macrouridae & & & & & & & & & \\
\hline Nezumia pulchella & Benthic & 0.5 & 0.6 & 0.8 & 0.1 & & & & \\
\hline Merlucciidae & & & & & & & & & \\
\hline Merluccius gayi & Benthic & 0.5 & 11.1 & 0.8 & 0.6 & 0.4 & 0.7 & 0.3 & $<0.1$ \\
\hline Scomberosocidae & & & & & & & & & \\
\hline Scomberesox saurus & Pelagic & 1.5 & 3.9 & 1.5 & 0.6 & & & & \\
\hline Unidentified fishes & & 9.9 & 24.0 & 15 & 34.4 & 21.8 & 12.6 & 15.7 & 21.6 \\
\hline Fish remains & & & 4.2 & 7.5 & 2.1 & & 3.6 & 6.7 & 1.0 \\
\hline Digested remains & & & 6.8 & 19.5 & 8.9 & & 11.0 & 29.8 & 13.2 \\
\hline $\operatorname{Mud}(*)$ & & & 8.0 & 9.0 & 4.9 & & 0.2 & 0.3 & $<0.1$ \\
\hline Total benthic prey & & 20.2 & 29.3 & 24.2 & 26.9 & 62.9 & 50.2 & 29.6 & 50.5 \\
\hline Total pelagic prey & & 59.1 & 20.6 & 11.1 & 13.7 & 3.1 & 3.7 & 1.9 & 0.2 \\
\hline Number of stomachs with food & & & & 1 & & & 3 & 12 & \\
\hline Total number of stomachs & & & & & & & 5 & 13 & \\
\hline
\end{tabular}

$\left(^{*}\right)$ included as dietary category as in Carrasson et al. (1992) and White et al. (2004). 
Table 2. Contribution (Contrib \%) to average dissimilarity by prey item and dietary index between A. nigra and B. canescens. Percentage by number (\%N); weight (\%W); frequency of occurrence (\%FO) and index of relative importance (\%IRI). The name of the Genus should be consulted on the Table 1 / Contribución (Contrib \%) a la disimilaridad por item presa e índice dietario entre A. nigra y B. canescens. Porcentaje numérico $(\%)$; gravimétrico (\%); frecuencia de ocurrencia (\%O) e índice de importancia relativa (\%RI). Para el nombre de los géneros se debe consultar la Tabla 1

\begin{tabular}{|c|c|c|c|c|c|c|c|}
\hline \multirow[b]{2}{*}{ Prey-item } & \multirow[b]{2}{*}{$\begin{array}{c}\text { Contrib } \\
\%\end{array}$} & \multicolumn{2}{|l|}{$\% W$} & \multicolumn{2}{|l|}{$\% \mathrm{FO}$} & \multicolumn{2}{|l|}{$\%$ IRI } \\
\hline & & Prey-item & $\begin{array}{c}\text { Contrib } \\
\%\end{array}$ & Prey-item & $\begin{array}{c}\text { Contrib } \\
\%\end{array}$ & Prey-item & $\begin{array}{c}\text { Contrib } \\
\%\end{array}$ \\
\hline E. mucronata & 16.51 & D. laternatus & 8.16 & Mud & 9.92 & D. laternatus & 11.23 \\
\hline D. laternatus & 12.34 & M. gayi & 7.70 & D. laternatus & 8.61 & Mud & 9.28 \\
\hline$H$. reedi & 8.52 & Mud & 7.21 & Unidentified cephalopods & 7.74 & Unidentified cephalopods & 9.03 \\
\hline L. parabranchia & 6.89 & H. reedi & 6.82 & L. parabranchia & 7.50 & H. reedi & 8.95 \\
\hline G. alata & 5.09 & S. saurus & 6.09 & Crustacean remains & 6.39 & Crustacean remains & 8.28 \\
\hline Unidentified fishes & 4.78 & Crustacean remains & 6.06 & S. saurus & 4.97 & E. mucronata & 7.76 \\
\hline P. armata & 4.35 & L. parabranchia & 5.07 & G. alata & 4.52 & Unidentified fishes & 5.23 \\
\hline M. gaudichaudii & 4.15 & G. alata & 4.92 & M. gaudichaudii & 4.52 & Unidentified myctophids & 4.71 \\
\hline Unidentified cephalopods & 4.08 & Unidentified crustaceans & 4.84 & Digested remains & 3.88 & L. parabranchia & 4.43 \\
\hline S. saurus & 3.84 & Unidentified cephalopods & 4.42 & Scopelosaurus sp. & 3.52 & S. saurus & 3.19 \\
\hline Unidentified crustaceans & 3.53 & Unidentified fishes & 4.14 & N. pulchella & 3.52 & Unidentified crustaceans & 3.13 \\
\hline$P$. acutifrons & 2.94 & M. gaudichaudii & 4.09 & P. chilensis & 3.52 & P. armata & 3.12 \\
\hline C. porteri & 2.94 & P. armata & 3.66 & L. iselinoides & 3.52 & M. gayi & 2.79 \\
\hline Scopelasaurus sp. & 2.22 & Unidentified myctophids & 3.29 & P. armata & 3.27 & Digested remains & 2.74 \\
\hline N. pulchella & 2.22 & C. porteri & 2.89 & P. acutifrons & 3.20 & G. alata & 2.22 \\
\hline P. chilensis & 2.22 & Scopelasaurus sp. & 2.60 & Unidentified myctophids & 3.12 & Fish remains & 2.03 \\
\hline L. iselinoides & 2.22 & H. diomedeae & 2.59 & Polychaeta & 2.26 & M. gaudichaudii & 1.83 \\
\hline \multirow[t]{3}{*}{ Polychaeta } & 2.08 & P. chilensis & 2.48 & H. diomedeae & 2.26 & C. johni & 1.51 \\
\hline & & N. pulchella & 2.34 & C. porteri & 2.26 & & \\
\hline & & Digested remains & 2.21 & S. suhmi & 2.26 & & \\
\hline Pelagic & 57.15 & Pelagic & 65.48 & Pelagic & 68.12 & Pelagic & 73.53 \\
\hline Benthic & 42.85 & Benthic & 34.52 & Benthic & 31.88 & Benthic & 26.47 \\
\hline
\end{tabular}

be the result either of direct mortality due to fishing and/ or post-release mortality, when the sharks are discarded. Most specimens of $B$. canescens captured comprised juveniles, while a significant part of the size structure of $A$. nigra was represented by adults. However, this may be well explained by the different depth range described for the two species and the depth range covered by this study; since our sampling covers most of the habitat of $A$. nigra and only the upper fourth of the depth range of $B$. canescens, while their adults have been found at deeper depths, in the Patagonian toothfish Dissostichus eleginoides fishery (Oyarzún et al. 2003).

Although Wetherbee et al. (1990) suggested that the occurrence of high proportions of empty stomachs in shark diet studies and in commercial fisheries operations is common, in our study this was confirmed only in A. nigra, with $32 \%$ of the stomachs with contents in general, and especially in males, where this percentage also clearly decreased with increasing sizes. On the other hand, $B$. canescens showed a higher percentage of stomachs with contents (61\%, for all sizes) and also the percentage increased with size, in both sexes.
Some authors have reported an opportunistic behaviour in the feeding habits of some deep-sea sharks (Mauchline \& Gordon 1983, Carrassón et al. 1992, Ebert et al. 1992) with species scavenging on fish carcasses (Bergstad et al. 2003). This behavior was observed in A. nigra feeding upon parts of prey such as Nezumia pulchella and Scomberesox saurus.

The diversity of diets of deep-sea sharks is characterized to consist of two groups of species. One feeding on relatively few prey classes and having a diet of low diversity and another one with more diverse diet and less restricted dietary composition (Mauchline \& Gordon 1985). According to our results, specifically those of $H^{\prime}, B$. canescens could be classified in the first category, while A. nigra in the second one.

Cortés (1999) in his analysis of the diet composition and trophic levels of several shark species, listed A. nigra as feeding mainly on decapod crustaceans and secondarily on fishes and cephalopods, although his data is based only in two specimens. In this study, the feeding habits of the species were confirmed, in terms of the kinds of prey, 
although fishes were more important and also feeding on euphausiids was found in smaller specimens, suggesting that the species has benthic as well as pelagic feeding habits through its life. The presence of micronektonic crustaceans such as euphausiids and other vertical migrants suggests direct links between the epipelagic production and the deep-living species (Bergstad et al. 2003). In addition, the diet of other deep-sea sharks that eat upon pelagic macroplankton and micronecton suggests a generalized benthopelagic foraging behaviour (Neiva et al. 2006). Sharks showing this kind of behaviour, feed upon myctophids and other mesopelagic fish and nektobenthic species that have a closer relationship with the sediment interface, but not upon epi or endobenthic prey (Neiva et al. 2006). This type of diet and behavior is closer to what was found in A. nigra.

Other deep-sea sharks are mainly benthic top predator and also scavengers (Cherel \& Duhamel 2004), such as species of the family Scyliorhinidae which show a diet composition based mainly in fishes and decapod crustaceans (Cortés 1999, Stergiou \& Karpouzi 2002). This study showed that $B$. canescens feeds mainly on decapod crustaceans and secondarily on fishes, suggesting that this species has epibenthic feeding habits.

Studies on deep-sea megafaunal community have indicated that larger predators such as sharks have a low depth overlap within the same trophic guild, indicative of high depth zonation with no bathymetric substitution of species (Cartes \& Carrassón 2004). One distribution pattern like this would explain the high trophic overlap of both species studied here. However, A. nigra has also diversified its trophic spectrum, exploiting pelagic prey and thus it has lowered the competition with $B$. canescens to a narrower depth range.

\section{ACKNOWLEDGMENTS}

We thank C. Vargas and P. Herrera for assistance in sample processing and all technical support of the Fisheries Laboratory at Universidad Católica del Norte-Coquimbo. The study was partially supported by fishing companies of Coquimbo and the Fisheries Research Fund (FIP), Chile. Editorial comments by John Stevens and two anonymous reviewers are deeply appreciated.

\section{LITERATURE CITED}

Acuña E \& JC Villarroel. 2002. Sharks and rays by-catched in the deep sea crustacean fishery off the Chilean coast. Shark News 14: 16.
Arancibia H \& R Meléndez. 1987. Alimentación de peces concurrentes en la pesquería de Pleuroncodes monodon Milne Edwards. Investigación Pesquera, Chile 34: 113-128.

Bergstad OA, ÅD Wik \& Ø Hildre. 2003. Predator-prey relationships and food sources of the skagerrak deep-water fish assemblage. Journal of Northwest Atlantic Fishery Science 31: $165-180$.

Burgess GH \& S Springer. 1986. The hook-tooth shark, Aculeola nigra De Buen (Family Squalidae) of the Eastern Pacific. In: Uyeno T, R Arai, T Tanuichi \& K Matsura (eds). Indo-Pacific fish biology, pp. 189-196. Proceedings of the Second International conference of Indo-Pacific Fishes, Ichthyological Society of Japan, Tokyo.

Carrassón M, C Stefanescu \& JE Cartes. 1992. Diets and bathymetric distributions of two bathyal sharks of the Catalan deep sea (western Mediterranean). Marine Ecology Progress Series 82: 21-30.

Cartes JE \& M Carrassón. 2004. Influence of trophic variables on the depth-range distributions and zonation rates of deepsea megafauna: the case of the Western Mediterranean assemblages. Deep-Sea Research I 51: 263-279.

Cherel Y \& G Duhamel. 2004. Antarctic jaws: cephalopod prey of sharks in Kerguelen waters. Deep-Sea Research I 51: 17-31.

Clarke KR. 1993. Non-parametric multivariate analyses of changes in community structure. Australian Journal of Ecology 18: $117-143$.

Clarke KR \& RN Gorley. 2001. Getting Started with PRIMER v5: User Manual/Tutorial. Primer-E, Plymouth.

Compagno LJV. 1984. FAO species catalogue. Sharks of the world. An annotated and illustrated catalogue of shark species known to date. FAO Fisheries Synopsis 125(4), Part 2: 251655.

Cortés E. 1997. A critical review of methods of studying fish feeding based on analysis of stomach contents: application to elasmobranch fishes. Canadian Journal of Fisheries and Aquatic Sciences 54: 726-738.

Cortés E. 1999. Standardized diet compositions and trophic levels of sharks. ICES Journal of Marine Science 56: 707717.

Ebert DA, LJV Compagno \& PD Cowley. 1992. A preliminary investigation of the feeding ecology of squaloid sharks off the west coast of southern Africa. South African Journal of Marine Science 12: 601-609.

Gartner JV, RE Crabtree \& KJ Sulak. 1997. Feeding at depth. In: Randall DJ \& AP Farrell (eds). Deep-sea fishes, pp. 115193. Academic Press, San Diego.

González J. 2001. Fauna íctica concurrente en la pesquería del camarón nailon, Heterocarpus reedi (Bahamonde, 1959), entre la II y IV Regiones ( $\left.25^{\circ} 01^{\prime} \mathrm{S}-36^{\circ} 04^{\prime} \mathrm{S}\right)$. Tesis de Biología Marina, Universidad Católica del Norte, Coquimbo, 168 pp.

Hyndes GA, ME Platell \& IC Potter. 1997. Relationships between diet and body size, mouth morphology, habitat and 
movements of six sillaginid species in coastal waters: implications for resource partitioning. Marine Biology 128: 585-598.

Krebs CJ. 1989. Ecological methodology, 654 pp. Harper \& Row, New York.

Kyne PM \& CA Simpfendorfer. 2007. A collation and summarization of available data on deepwater chondrichthyans: biodiversity, life history and fisheries. A report prepared by the IUCN SSC Shark Specialist Group for the Marine Conservation Biology Institute, 137 pp. [online] <http://www.flmnh.ufl.edu/fish/organizations/ssg/ deepchondreport.pdf $>$

Manning R. 1968. A revision of the family squillidae (Crustacea, Stomatopoda) with the description of eighth new generals. Bulletin of Marine Science 18: 105-142.

Mauchline J \& L Fisher. 1969. The biology of euphausiids. Advances in Marine Biology 7: 1-454. Academic Press, London

Mauchline J \& JDM Gordon. 1983. Diets of the sharks and chimaeroids of the Rockall Trough, northeastern Atlantic Ocean. Marine Biology 75: 269-278.

Mauchline J \& JDM Gordon. 1985. Trophic diversity in deepsea fish. Journal of Fish Biology 26: 527-535.

Meléndez R \& D Meneses. 1989. Tiburones del talud continental recolectados entre Arica $\left(18^{\circ} 19^{\prime}\right.$ S) e Isla Mocha (38³0’S), Chile. Investigaciones Marinas 17: 3-73.

Neiva J, R Coelho \& K Erzini. 2006. Feeding habits of the velvet belly lanternshark Etmopterus spinax (Chondrichthyes: Etmopteridae) off the Algarve, southern Portugal. Journal of the Marine Biological Association of the United Kingdom 86: 835-841.

Nelson JS. 1994. Fishes of the world, 600 pp. John Wiley \& Sons, New York.

Oyarzún C, S Gacitúa, M Araya, L Cubillos, R Galleguillos, C Pino, G Aedo, M Salamanca, M Pedraza \& J Lamilla. 2003. Monitoreo de la pesquería artesanal de bacalao de profundidad entre la VIII y XI Regiones. Informes Técnicos FIP. FIP/IT No 2001-16: 1- 247. <http:// http://www.fip.cl/ Proyectos.aspx $>$
Papastamatiou YP, BM Wetherbee, CG Lowe \& GL Crow. 2006. Distribution and diet of four species of carcharhinid shark in the Hawaiian Islands: evidence for resource partitioning and competitive exclusion. Marine Ecology Progress Series 320: 239-251.

Pequeño G. 1989. Peces de Chile. Lista sistemática revisada y comentada. Revista de Biología Marina 24: 1-132.

Pinkas L, MS Oliphant \& ILK Iverson. 1971. Foods habits of albacore, bluefin tuna, and bonito in California waters. California Fish and Game 112: 1-105.

Retamal M. 1994. Los decápodos de Chile, 256 pp. Dirección de Docencia, Universidad de Concepción, Concepción.

Roper CFE, MJ Sweeney \& CE Nauen. 1984. Cephalopods of the world. FAO Fisheries Synopsis 125 (3): 1-277

Shuozeng D. 1995. Food utilization of adult flatfishes cooccurring in the Bohai Sea of China. Netherlands Journal of Sea Research 34: 183-193.

Stergiou KI \& VS Karpouzi. 2002. Feeding habits and trophic levels of Mediterranean fish. Reviews in Fish Biology and Fisheries 11: 217-254.

Stevens JD, R Bonfil, NK Dulvy \& PA Walker. 2000. The effects of fishing on sharks, rays, and chimaeras (chondrichthyans), and the implications for marine ecosystems. ICES Journal of Marine Science 57: 476-494.

Wetherbee BM, SH Gruber \& E Cortés. 1990. Diet, feeding habits, digestion, and consumption in sharks, with special reference to the lemon shark, Negaprion brevirostris. In: Pratt HL, SH Gruber \& T Taniuchi (eds). Elasmobranchs as living resources: Advances in the biology, ecology, systematics, and the status of the fisheries. NOAA Technical Report NMFS 90: 29-47.

White WT, ME Platell \& IC Porter. 2004. Comparisons between the diets of four abundant species of elasmobranchs in a subtropical embayment: implications for resource partitioning. Marine Biology 144: 439-448. 